\section{Common sense and professional opinion are still important}

\author{
Hamish Ashton
}

Kia ora (welcome) to this New Zealandguided issue of BJSM, the journal I like to think of as BJSP-British Journal of Sports Physiotherapy-but don't let the folks up north know that! In 2018 I was struck by the prominent voices pushing the biopsychosocial model of patient management. That model, as I recall it, started as a model for non-specific (chronic) low back pain but that approach is now being expounded as the way forward for all our musculoskeletal issues.

As a practitioner of 30 years I feel I have been using this model for many a year. I have treated every individual who walks in my door as a person with a specific problem. I have listened, and talked (in that order I hope), and used the set of skills that I honed over many years. Some patients' problems were a bit more bio, some a bit more psycho, and some a bit more socially biased.

I have also used my diagnostic skills to develop a working diagnosis of the problem to help me and them understand the problem. This may not be an exact diagnosis, and in the process of treating them it may be refined or changed as I understand the problem more (or less). Having this diagnosis helps me decide on which components of treatment are most likely to work, in my experience, as well as helps the patient understand what we are trying to do in our management plan.

An interesting article in The BMJ has just come to my attention-Parachute use to prevent death and major trauma when jumping from aircraft: an RCT' (https://doi. org/10.1136/bjm.k5094). I find it interesting that, despite parachutes being around for hundreds of years, this is the first RCT looking at whether they work or not in preventing deaths. I will let you read it for the conclusion and to assess its overall contribution to the field of injury management. And despite there being just one study on this topic, I think next time I am about to jump out of a plane I will go with expert opinion of many years duration and not leave the parachute behind.

The same goes for my diagnostic and manual skills. I may not be able to determine that C4 moves $2 \mathrm{~mm}$ and C5 $4 \mathrm{~mm}$ but I feel something in people with neck pain and that information helps me decide

Private Practitioner, Tauranga, New Zealand

Correspondence to Mr Hamish Ashton, Tauranga, New Zealand; hamish@p2pphysio.nz good patient management.

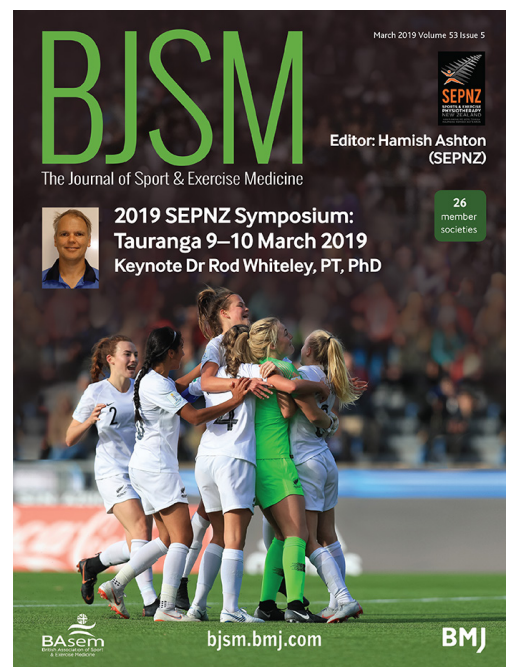

Figure 1 Join us at New Zealand's coastal playground-Tauranga in the Bay of Plentyfor Sports \& Exercise Physiotherapy New Zealand's (SPENZ) fifth Biennial symposium.

in my experience what management is more likely to work with that person. It may be that just that the touch gives the patient confidence in me as a practitioner and it's all placebo (remember Shamans used to be able to kill members of their tribe just by saying they are going to die). It may be that I do something else, may be some symptom modification. However, I am not giving up on things just because they can't yet be fully explained, as long as I am still looking at the larger picture of

\section{IN THIS ISSUE: PRACTICAL PEARLS}

I chose papers for this issue for their practical content. Although research is useful, its application is what is needed at the coal front of injury management.

Having had a number of ACL reconstructions come through my clinic door recently, many with very poor quads function, the paper by Bertrand Sonnery-Cottet (see page 289) comes as a timely reminder of the best way forward on this, and sometimes simple solutions are the best answer.

As a practitioner working in the sports field for 25 years I find great enjoyment in seeing athletes perform and do well. The worst job I feel I have is telling them they can't play. Spending more time preventing than treating injuries would be ideal. But what we do and what works is often not clear.

We feature three illuminating papers. First Roland Rössler (see page 309) looks not only at the effect of the Kids FIFA11 + warmup but its cost-effectiveness. Next Bradley S Neal (see page 270) addresses the risk factors for the conundrum of patellofemoral pain. This is an injury that there has been much said in the past but not some much agreed on in its prevention and management. Finally, Romana Brunner (see page 282) addresses lower limb injury prevention programmes. Though we all hope these work, it is good to have this backed by further research.

As a sign off, good communication is key to success. Jan Ekstrand (see page 304) addresses the issue of communication between the medical team and the coach/manager. Over the last few years we have seen some great examples of this not working (may I cough and say 'Jose Mourinho, nothin' here or will that get me sued?). Does good communication actually make a difference? We hope so! Enjoy the paper and make your own conclusions.

Our fifth biennial symposium-Radical Rod Whiteley and more!

Sports \& Exercise Physiotherapy New Zealand celebrates its fifth Biennial symposium on March 9 and 10, 2019. Join us at the Bay of Plenty! We have a reputation for practical content and that's what's on offer-just like the choices of papers for this issue. Tips you can use in the clinic. That's just one reason we chose Aspetar giant Dr Rodney Whiteley-PT and PhD_as our keynote. He can match the chat with the best of the PhDs but he smashes them when it comes to sharing what he does in the clinic. He's the veritable triple threat-he knows the science, he knows how to treat patients, and he knows how to explain the first two. I'm looking forward to seeing you there! Follow SEPNZ on Twitter (@SportsPhysioNZ) and our home page is: https:// sportsphysiotherapy.org.nz/

HA-SEPNZ Exec Member and Private Practitioner.hamish@p2pphysio.nz

\section{Competing interests None declared,}

Patient consent for publication Not required.

Provenance and peer review Commissioned; internally peer reviewed.

(c) Author(s) (or their employer(s)) 2019. No commercial re-use. See rights and permissions. Published by BMJ.

\section{Check for updates}

To cite Ashton H. Br J Sports Med 2019;53:263.

Br J Sports Med 2019;53:263.

Accepted 22 January 2019

doi:10.1136/bjsports-2019-100617 